\title{
Mikrodalga destekli reaktörde pilot ölçekli rafine ve atık ayçiçek yağından biyodizel üretimi
}

\author{
Veli Gökhan DEMIIR ${ }^{1, *}$, Nadir ILTEN ${ }^{1}$, Hakan Serhad SOYHAN²

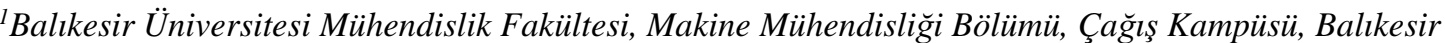 \\ ${ }^{2}$ Sakarya Üniversitesi Mühendislik Fakültesi, Makine Mühendisliği Bölümü, Esentepe Kampüsü, \\ Serdivan, Sakarya
}

Geliș Tarihi (Recived Date): 31.01 .2018

Kabul Tarihi (Accepted Date): 05.06.2018

\section{Özet}

Kimyasal bir reaksiyon olan transesterifikasyon, biyodizel üretiminde en yaygın kullanılan yöntemdir. Mikrodalga ısitma sistemi kullanılarak gerçekleştirilen transesterifikasyon reaksiyonlarında, konvansiyonel sistemlere klyasla büyük oranda hız ve verim artışı sağlandiğ bilinmektedir. Yapılan literatür taramasında, mikrodalga teknolojisi ile gerçekleştirilen biyodizel üretimlerinin yalnızca laboratuvar ölçeklerinde sınırlı kaldı̆̆g, henüz pilot ya da büyük ölçekte bir üretimin gerçekleştirilemediği görülmüşı̈̈r. Bu çalışmada; tasarlanıp imal edilen mikrodalga destekli biyodizel reaktörü kullanılarak, bazik transesterifikasyon yöntemi ile mikrodalga ışıma altında rafine ve atık ayçiçek yağlarından pilot ölçekte biyodizeller üretilmiştir. Deneylerde sabit reaksiyon koşulları (6:1 molar metanol:yă̆, \%1.0 $\left.\mathrm{KOH}\left(m_{\mathrm{KOH}} / m_{y a g ̆}\right), 60^{\circ} \mathrm{C}\right)$ altında reaksiyon süresinin transesterifikasyon tamamlanma oranı ve temel biyodizel özellikleri üzerindeki etkisi incelenmiştir. Ayrıca, rafine ayçiçek yă̆ından hem mikrodalga ışıma altında, hem de reaktördeki konvansiyonel ısıtma sistemi (elektrikli rezistans) kullanılarak biyodizel numuneleri üretilmiş, böylece iki metodun net olarak kıyaslanması sağlanmıştır. Elde edilen sonuçlara göre; mikrodalga ısıtma sistemi kullanımında rafine ayçiçek yağı transesterifikasyonun 5 dakika sonunda tamamlandığl, konvansiyonel ısitma sistemi kullanımında ise 60 dakika sonunda dahi yeterli ester içeriğine sahip biyodizelin üretilemediği ve reaksiyonun tamamlanabilmesi için daha uzun reaksiyon sürelerine ihtiyaç duyulduğu tespit edilmiştir. Atık ayçiçek yă̆ kullanımında ise belirlenen reaksiyon koşullarında istenen düzeyde dönüşümünün sağlanamadı̆̆g, ancak literatürdeki benzer konvansiyonel transesterifikasyon reaksiyonlarına göre çok daha kısa sürede ve daha yüksek verimle metil ester elde edilebildiği gözlemlenmiştir.

Anahtar kelimeler: Rafine ayçiçek yă̆g, atık ayçiçek yağl, mikrodalga, biyodizel.

\footnotetext{
*Veli Gökhan DEMIIR, veligokhandemir@balikesir.edu.tr, https://orcid.org/0000-0002-5667-1909

Nadir İLTEN, nilten@balikesir.edu.tr, https://orcid.org/0000-0003-4009-5078

Hakan Serhad SOYHAN, hsoyhan@sakarya.edu.tr, https://orcid.org/0000-0003-3723-9640
} 


\title{
Pilot scale biodiesel production from refined and waste sunflower oils in microwave assisted reactor
}

\begin{abstract}
Transesterification, which is a chemical reaction, is the most commonly used method in biodiesel production. It is known that in transesterification reactions, using microwave heating system increases the reaction rate and efficiency in comparison with the conventional systems. According to the literature review, it is seen that biodiesel productions using microwave technology are limited only with the laboratory scales, and no pilot or large scale productions have not been realized yet. In this study, pilot scaled biodiesels are produced from refined and waste sunflower oils with basecatalyzed transesterification method under microwave irradiation by using the designed and manufactured microwave assisted reactor. In the experiments, under constant

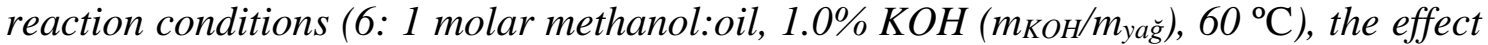
of the reaction time on the transesterification completion rate and the main biodiesel properties are examined. In addition, the biodiesel samples are produced from refined sunflower oil both with the microwave system and conventional heating system (by electric resistance) which is located in the reactor, thus a clear comparison of the two methods is obtained. According to the results, it is found that the refined sunflower transesterification is completed at the end of the 5 minutes by using microwave heating system, however the biodiesel having desired ester content level can not be produced even in 60 minutes, and longer reaction times are needed in order to complete the reaction by using conventional heating system. It is also observed that with the use of waste sunflower oil, under the defined reaction conditions, the conversion at the desired level cannot be achieved, however the methyl esters can be obtained in a much shorter time and in a higher efficiency than the similar conventional transesterification reactions existing in the literature.
\end{abstract}

Keywords: Refined sunflower oil, waste sunflower oil, microwave, biodiesel.

\section{Giriş}

Gün geçtikçe azalan fosil yakıt rezervleri, artan enerji ihtiyacı ve çevresel kaygılar enerji üretiminde petrol, kömür gibi fosil yakıtlar yerine yenilenebilir enerji kaynaklarının kullanımını teşvik etmektedir. Biyokütle, yenilenebilir enerji kaynakları içinde en büyük potansiyele sahip olan kaynak türüdür. Biyokütleden elde edilen biyoyakıtlar içerisinde, dizel motorlarda kullanılan motorine alternatif en önemli yakıt biyodizeldir [1]. Motorine benzer yakıt karakteristiğine sahip olan biyodizel, dizel motorlarda kısmi modifikasyonlarla ya da modifikasyon yapılmadan direkt olarak kullanılabilmektedir [2]. Biyodizel, genellikle 16 - 20 aralığında karbon atomu içeren hidrokarbon zincirlerinden meydana gelmektedir ve biyodizel ağırlığının yaklaşık \% $11^{\prime} \mathrm{i} \mathrm{O}_{2}$ ' den oluşmaktadır [1,3]. Biyodizelin yapısında bulunan $\mathrm{O}_{2}$, yanma odasındaki oksidant miktarını artırarak $\mathrm{HC}$ ve $\mathrm{CO}$ emisyonlarında önemli iyileştirmeler sağlamaktadır. Ayrıca biyodizelin aromatik ve sülfür bileşiği içermemesi, egzoz 
emisyonlarında poliaromatik hidrokarbon $(\mathrm{PAH})$ ve PM-İs seviyesinin oldukça düşük çıkmasına neden olmaktadır [4].

Biyodizel genellikle bitkisel yağlardan veya hayvansal yağlardan üretilen, uzun zincirli yăg asidi mono alkil esteri olarak ifade edilmektedir. Biyodizel üretiminde kullanılan bitkisel yağların çeşidi, yağ bitkisinin yetiştirildiği bölgenin iklimsel ve coğrafi özelliklerine göre değişmektedir. Örneğin; Amerika Birleşik Devlerinde en yaygın kullanılan hammadde soya fasulyesi yağı iken, Avrupa'da kanola (kolza) yağı, tropikal bölge ülkelerinde ise palmiye yağıdır [5]. Biyodizel üretiminde en yaygın kullanılan yöntem, kimyasal bir ester dönüşüm reaksiyonu olan transesterikasyondur. $\mathrm{Bu}$ yöntemde yağların bir katalizör varlığında metanol gibi kısa zincirli bir alkol ile tepkimeye sokularak yeniden esterleşmesi sağlanır. Böylece yağın yapısında bulunan yoğun ve viskozitesi çok yükssek olan gliserol uzaklaştırılır ve moleküler ağırlığı üç kat, viskozitesi ise yaklaşık sekiz kat oranında azaltılmış olan yağ asidi metil esterleri (YAME) diğer adıyla biyodizel elde edilmiş olur [6]. Şekil 1'de gösterdiği üzere ideal bir transesterifikasyon reaksiyonunda; 1 mol yağ, 3 mol metanol ile reaksiyona girerek 3 mol metil ester ve 1 mol reaksiyon yan ürünü olan gliserol oluşturmaktadır.

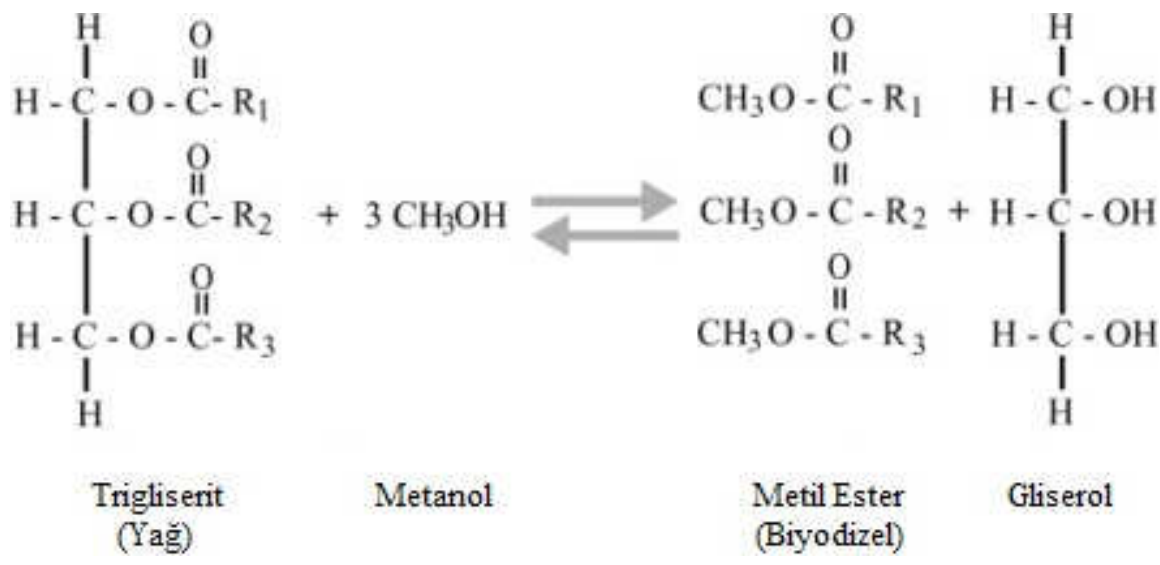

Şekil 1. Transesterifikasyon reaksiyonu gösterimi.

Transesterifikasyon reaksiyonunu hızlandırmak ve ester (biyodizel) dönüşümünü artırmak için genellikle asit, baz (alkali) ya da enzim gibi katalizör çeşitleri kullanılmaktadır. Diğer katalizörlere göre çok hızlı olan baz katalizörler; düşük reaksiyon sıcaklığı ve alkol miktarı gereksinimi ve daha az korozif olması (aside göre) gibi özelliklerinden dolayı ticari biyodizel üretimlerinde (transesterifikasyon ile) çok yaygın olarak tercih edilmektedir [3]. Asit katalizörler ise genellikle yüksek miktarda serbest yağ asidi içeren (>\%0.5) yağların esterlerine dönüştürüldüğü esterifikasyon reaksiyonlarında (ön iyileștirme) kullanılır. Transesterifikasyon reaksiyonlarında etanol, isopropranol ve bütanol gibi alkoller kullanılabilse de diğer alkollere kıyasla yüksek verimli dönüşüm sağlaması ve düşük maliyeti gibi avantajlarından dolayı en yaygın tercih edilen alkol türü metanoldür [7].

Konvansiyonel sistemler ile gerçekleştirilen transesterifikasyon reaksiyonlarında karşılaşılan; düşük seçicilik oranı, uzun reaksiyon ve faz ayrımı (biyodizel-gliserol) süreleri ve reaksiyon karışımının 1sıtılması için harcanan yüksek enerji miktarı gibi olumsuzluklar araştırmacıları biyodizel üretimlerinde mikrodalga 1şıma gibi alternatif 1sitma sistemlerini kullanmaya yöneltmiştir [8,9]. Elektromanyetik bir dalga türü olan mikrodalga, elektromanyetik dalga spektrumunun $300 \mathrm{MHz}-300 \mathrm{GHz}$ bandındaki 
frekans grubunu ifade etmektedir. Geniş bir kullanım alanına sahip mikrodalga, kimyasal sentezlemede kullanılan reaktörlerin genelinde ve tüm ev tipi mikrodalga firınlarda $12.25 \mathrm{~cm}$ dalga boylu $2450 \mathrm{MHz}$ frekans değerinde kullanılmaktadır [10]. Mikrodalga teknolojisi kullanılarak gerçekleştirilen reaksiyonlarda; reaksiyon süresinin çok kısalması, yan reaksiyonları azalması ve verim artışı, kimyasal maddelerin direkt olarak 1sıtılması, 1sıtmanın doğrudan ve merkezden gerçekleştirilmesiyle 1sıtmada enerji kaybının azalması gibi avantajlar elde edilmektedir [11, 12]. Hernando ve ark [13] mikrodalga 1şıma altında geçekleştirdikleri bazik transesterifikasyon optimizasyon çalışmasında, soya ve kanola yağından 1 ila 5 dakikalık reaksiyon süreleri sonunda \%97'ye varan biyodizel verimi elde etmişlerdir. Araştırmacılar, mikrodalga ile gerçekleştirilen biyodizel üretimlerinin konvansiyonel sistemlere göre çok daha hızlı gerçekleştiğini ve reaksiyon sonunda daha az yan ürün oluştuğunu raporlamışlardır. Azcan ve Danişman [14] mikrodalga sentez ünitesi kullanarak gerçekleştirdikleri bazik pamuk yağı biyodizel dönüşümlerinde, 7 dakika sonunda en yüksek dönüşüm verimi (\%92.7) ve en yüksek ester içeriğine (\%99.7) sahip pamuk yağı metil esterini elde etmişlerdir. Araştırmacılar aynı reaksiyon koşullarında $(1.5 \% \mathrm{KOH}, 6: 1 \mathrm{molar}$ metanol:yağ, $60^{\circ} \mathrm{C}$ ) gerçekleştirdikleri konvansiyonel üretim ile benzer reaksiyon çıtılarına 30 dakikalık reaksiyon ile ulaşabilmişlerdir. Encinar ve ark [15] soya fasulyesi yağından hem konvansiyonel hem de mikrodalga destekli gerçekleştirdikleri bazik transesterifikasyonlar ile biyodizel üretmişlerdir. 6:1 molar oranında metanol, \%1 $\mathrm{KOH}$ varlığında yürütülen reaksiyonlarda; mikrodalga 1şıma ile 3 dakika, konvansiyonel 1sitma ile ise 60 dakika sonunda optimum yakıt özelliklerine sahip biyodizel numuneleri elde edilmiştir. Suryanto ve ark. [16] yaptıkları çalışmada, hindistancevizi yağından mikrodalga 1şıma ile biyodizel üretimi için optimum reaksiyon koşullarının; 6:1 metanol:yağ oranı, yağın ağırlıkça \%1'i kadar $\mathrm{NaOH}, 100 \mathrm{~W}$ mikrodalga çıkış gücü ve 5 dakika reaksiyon süresi olduğunu aktarmışlardır. Benzer birçok çalışmada, mikrodalga teknolojisi kullanılarak gerçekleştirilen bazik transesterifikasyon reaksiyonlar ile konvansiyonel metotlara göre çok kisa sürelerde ve yüksek verimde biyodizel üretilebildiği belirtilmektedir. Ancak yapılan literatür taramalarında, mikrodalganın büyük hacimlerde kullanılmasını engelleyen sınırlandırmalar (genellikle mikrodalganın kısıtlı dalma derinliği ve güvenlik sorunları) neticesinde bu çalışmaların yalnızca küçük ölçekte ve laboratuvar koşullarında gerçekleştirilebildiği görülmüştür.

Bu doğrultuda çalışmanın amacı, pilot ölçekte üretim yapabilen bir mikrodalga destekli biyodizel reaktörü tasarlayıp imal etmek ve bu reaktörde bazik transesterifikasyon yöntemi kullanarak temel yakıt özellikleri EN 14214 Avrupa biyodizel standartlarına uygun biyodizel üretmek olarak belirlenmiştir. Yapılan deneysel çalışmalarda; imal edilen reaktörde, Türkiye'de en çok üretimi gerçekleştirilen yağ olan ayçiçek yağı ve bu yağın kızartma işleminde kullanılması sonucu oluşan atık ayçiçek yağı kullanılarak mikrodalga 1şıma altında ayçiçek yağı metil esterleri üretilmiştir. Deneylerde sabit reaksiyon koşulları (6:1 molar metanol:yağ, \%1.0 $\left.\mathrm{KOH}\left(\mathrm{m}_{\mathrm{KOH}} / \mathrm{m}_{\text {yağ }}\right), \quad 60^{\circ} \mathrm{C}\right)$ kullanılarak, reaksiyon süresinin transesterifikasyon tamamlanma oranı ve temel biyodizel özellikleri üzerindeki etkisi incelenmiştir. Ayrıca, mikrodalga ve konvansiyonel metotlar ile aynı şartlar altında, aynı reaktörde ayçiçek yağından biyodizel üretimleri gerçekleştirilerek iki metodun net olarak kıyaslaması sağlanmıştır. 


\section{Deneysel çalışmalar}

\subsection{Mikrodalga destekli biyodizel reaktörï}

Bir bütün olarak biyodizel üretim sistemi, güvenlik boşluğuyla beraber $60 \mathrm{~L}$ dolum kapasitesi olan mikrodalga destekli reaktör ve saflaştırma ünitesinden oluşmaktadır. Saflaştırma ünitesinde konvansiyonel biyodizel üretim sistemlerinde yaygın olarak kullanılan sulu yıkama metodu ile saflaştırma işlemi yapılmaktadır. Sistemde sulu yıkamanın tercih edilme nedeni, bu tekniğin biyodizelin saflaştırılması için en iyi yöntemlerden biri olarak gösterilmesi ve sulu yıkama ünitesi kurulumunun alternatif sistemlere nazaran daha basit ve düşük maliyetli oluşudur [17]. Ünitede yıkama işlemi; su tankında 1sıtılan suyun (ort. $55^{\circ} \mathrm{C}$ ), saflaştırma tankı içinde karıştırılmakta olan ham biyodizelin üzerine duşlama yöntemiyle püskürtülmesiyle gerçekleştirilmektedir. Yıkanan biyodizelin kurutulması yine bu ünite içerisinde, elektrikli rezistans kullanılarak yapılmaktadır. Biyodizel üretim sisteminin ana ünitesi olan reaktör ise güç ünitesi, reaktör kapağı ve reaktör tankı bileșenlerinden oluşmaktadır. Güç ünitesinde; yüksek gerilim transformatörleri ve diyotları, kondansatörler, kontaktörler, PLC sistemi ve reaktör kontrolünün sağlandığı kontrol ekranı bulunmaktadır. Reaktör kapağında; mikrodalgaların üretildiği, $2.45 \mathrm{GHz}$ frekansta çalışan $0.9 \mathrm{~kW}$ gücünde 4 adet magnetron, mikrodalgaları yönlendiren dalga kılavuzları, emiş fanı, manometre, emniyet ventili, mekanik karıştırıcı (elektrik motoru+redüktör) ve yağ/reaktan giriş ağzı bulunmaktadır. Reaktörde asıl (mikrodalga) ve alternatif (konvansiyonel) olmak üzere 2 adet 1sitma sistemi vardır. Reaktör kontrol ekranından 1sitma sistemi ve reaksiyon sicaklığı seçilebilmektedir. Elektrik rezistanslı konvansiyonel 1sıtma sistemi, aynı reaksiyon koşullarında gerçekleştirilecek mikrodalga ve konvansiyonel üretim metotlarının mukayese edilebilmesi ve mikrodalga 1sıtma sisteminin arızası durumunda alternatif 1sıtma sistemi olarak kullanılabilmesi için reaktöre eklenmiştir. Reaktör tankı tasarım olarak mikrodalganın büyük hacimlerde kullanımını sınırlandırıcı özelliklerinden dolayı konvansiyonel reaktörlerden bazı farklılıklar içermektedir. Mikrodalgalar etki ettiği maddelerin dielektrik özelliklerine göre değișen, penetrasyon derinliği olarak da bilinen farklı dalma derinliklerine sahiptir. Mikrodalga teknolojisinin büyük hacimlerde etkin ve yaygın olarak kullanılamamasının temel nedeni, genellikle çok kısa uzunluk değerlerinde olan dalma derinleridir $\left(\mathrm{d}_{\mathrm{d}}\right)$. Mikrodalga kullanımda dikkat edilmesi ve mikrodalga teknolojisinin kullanıldığı sistemlerde göz önünde bulundurulması gereken diğer bir nokta, mikrodalganın metal malzemeler gibi yansitıcı yüzeylere veya sivri noktalara etki ettiğinde meydana gelebilen ark oluşumlarıdır. Bu kıstaslar hesaba katılarak pilot ölçekteki biyodizel reaktörü tasarımı yapılmıştır. Tablo 1 'de $2.45 \mathrm{GHz}$ mikrodalga frekansında, genel olarak sıvı bitkisel yağların $25^{\circ} \mathrm{C}$ ve $60^{\circ} \mathrm{C}$ sıcaklıklardaki ortalama dielektrik özellikleri $\left(\varepsilon^{\prime}\right.$, dielektrik sabiti; $\varepsilon^{\prime \prime}$, dielektrik kayıp faktörü) ve dalma derinlikleri verilmiştir. Bu değerler göz önüne alınarak reaktör, tam kapasite doldurulduğunda tank içi sıvı yüksekliği $25 \mathrm{~cm}$ olacak şekilde tasarlanmıştır.

Tablo 1. 2.45 GHz m.dalga frekansında bitkisel yağların ort. dielektrik özellikleri [18].

\begin{tabular}{|c|c|c|c|}
\hline Sicaklık & $\boldsymbol{\varepsilon}^{\prime}$ & $\boldsymbol{\varepsilon}^{\prime \prime}$ & dd (cm) \\
\hline $25^{\circ} \mathrm{C}$ & 2.5 & 0.1 & 23.7 \\
\hline $60^{\circ} \mathrm{C}$ & 2.6 & 0.2 & 19.5 \\
\hline
\end{tabular}

Endüstriyel mikrodalga ünitelerinde (kurutucular, fırınlar vb.) ark oluşumunun önlenmesi ve güvenli çalışma ortamının oluşturulması için cihazların iç hacimleri 
genellikle koruyucu boya ile boyanmaktadır. Biyodizel üretiminde kullanılan metanol ve asit/baz katalizörlerin boyayı çözücü ve aşındırıcı etkisi vardır. Bu nedenle reaktör iç hacmi ve reaktör tank bileșenleri koruyucu boya yerine endüstride "teflon" adiyla bilinen, mikrodalgayı geçirgen politetrafloroetilen polimer malzeme ile kaplanmıştır. Kullanılacak ortamın özelliklerine ve temas ettiği yüzeye göre teflon malzemenin çeşidi, dolayısıyla da karakteristik özellikleri değişmektedir. Reaktörde tercih edilen teflon çeşidi; akışkanın hızına asgari düzeyde etki eden yüzey pürüzlülüğü olan, yüksek abrasiv ve kimyasal aşınma direncine sahip, $205^{\circ} \mathrm{C}$ 'eye kadar yüksek sicaklık değerlerine dayanıklı ve metallere iyi derece tutunabilen Whitfort Xylan®cf 884 marka ve modelidir. Konvansiyonel biyodizel reaktörlerde etkin bir karıştırma işleminin gerçekleştirilebilmesi için genellikle tek bir karıştırma sisteminin kullanılması yeterli görülmektedir. Ancak tasarlanan reaktörde hem hızlı ve homojen bir karışım elde etmek, hem de mikrodalganın tüm karışıma etkiyebilmesi için mekanik karıştırıcı (280 d/d) ve sirkülasyon pompasının $(60 \mathrm{~L} / \mathrm{m})$ eşzamanlı olarak çalıştırıldığı bir karıştırma sistemi tercih edilmiştir. Şekil 2'de reaktör ana gövdesinin tasarımı için çizilen, reaktör bileşenlerinin gösterildiği patlatılmış teknik resim; Şekil 3'te ise teflon kaplanmış reaktör iç hacmi ve bileşenleri gösterilmiştir.

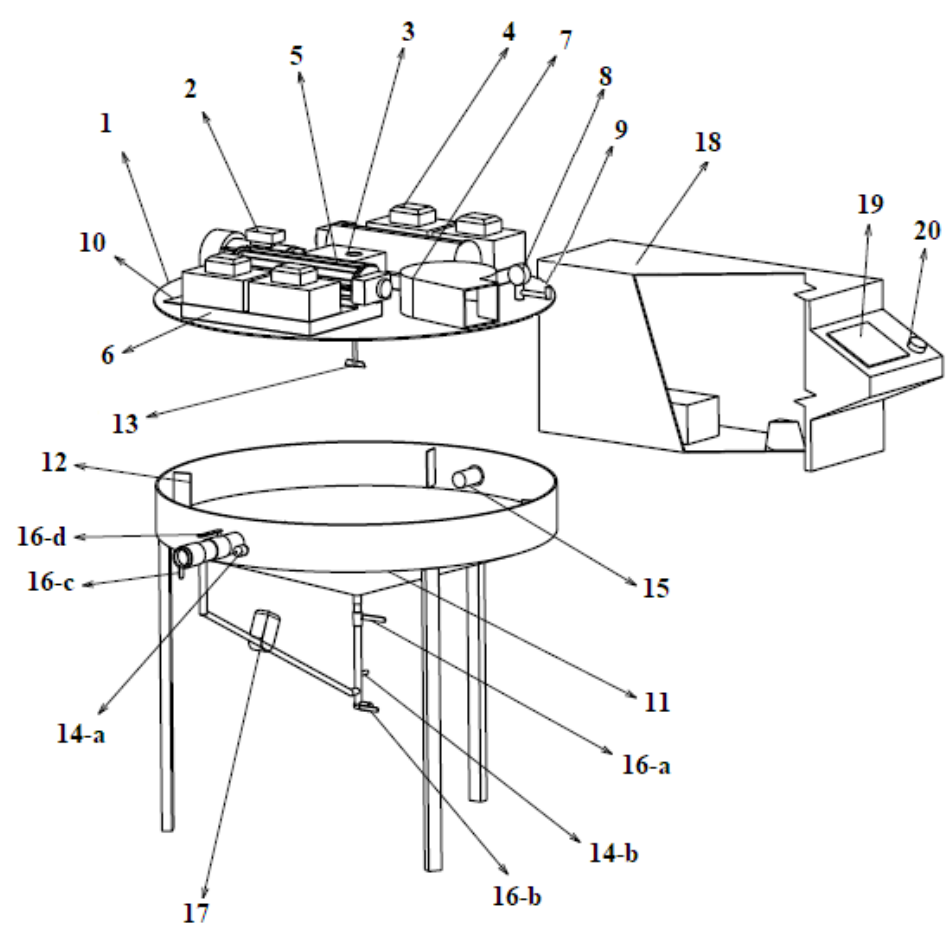

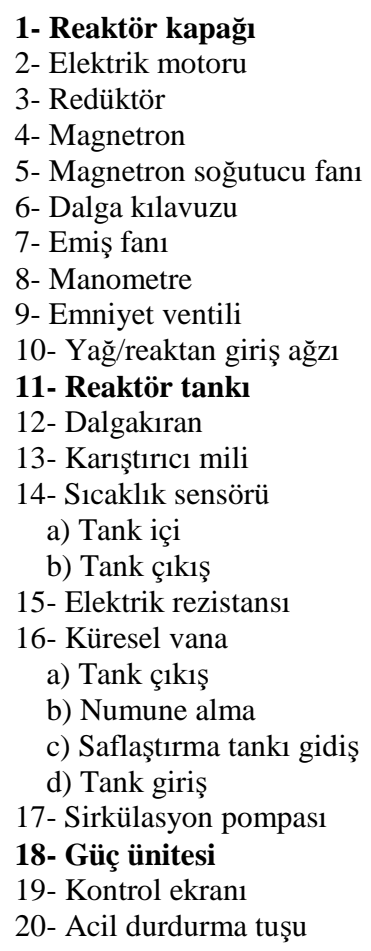

Şekil 2. Pilot ölçekli mikrodalga destekli biyodizel reaktörü tasarımı. 

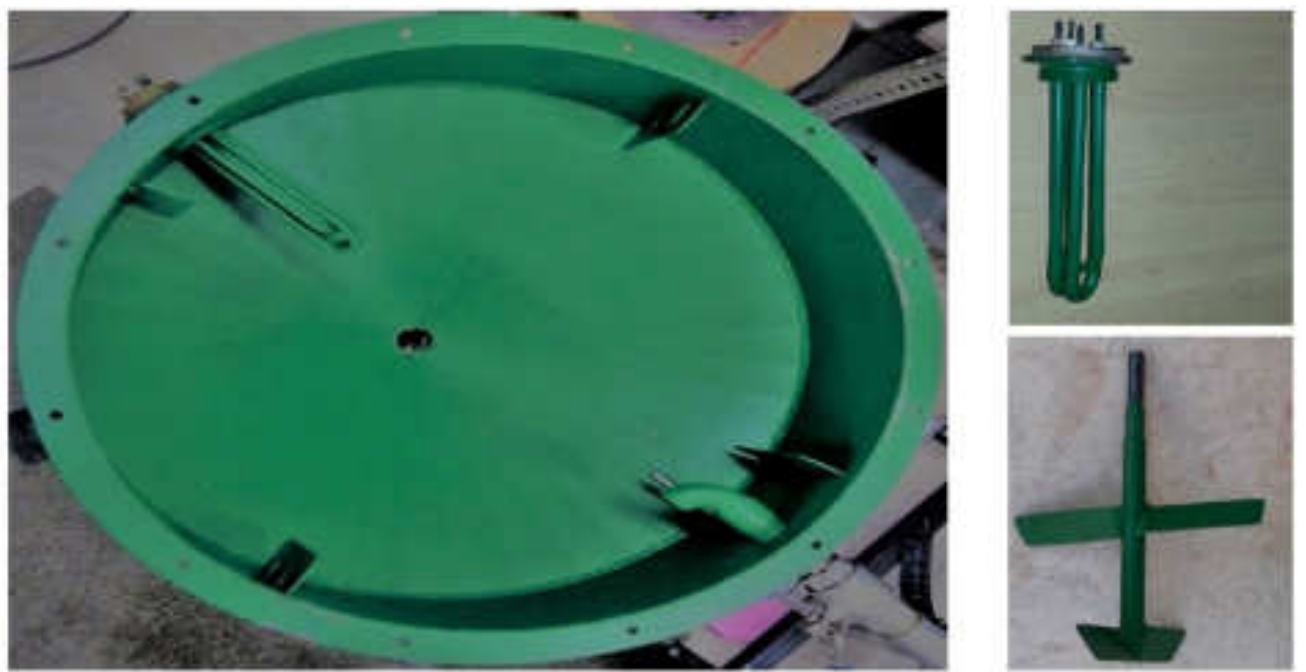

Şekil 3. Teflon malzeme ile kaplanan reaktör iç hacmi ve bileşenleri.

\subsection{Biyodizel üretimi}

\subsubsection{Kullanulan yă̆ ve kimyasallar}

TUIKK'in yayınladığı, 2011-2016 yıllarını kapsayan Türkiye'nin 5 yıllık yağlık bitki üretim verilerine göre, Türkiye'de son y1llarda en çok yetiştirilen yağlı tohum bitkisi ayçiçektir [19]. Dolayısıyla, biyodizel üretimlerimizde bitkisel yağ olarak rafine ayçiçek yağı (RAY) ve Balıkesir yöresinde çokça tüketilen lokma adlı hamur işi yiyeceğin kızartma işleminde kullanılan atık ayçiçek yağı (AAY) kullanılmıştır. Transesterifikasyon reaksiyonlarında alkol olarak metanol, baz katalizör olarak ise $\mathrm{KOH}$ tercih edilmiştir. Deneylerde kullanılan yağların yăg asidi kompozisyonları ve bazı fiziksel ve kimyasal özellikleri Tablo 2 ve Tablo 3'te verilmiştir. Yağların ortalama molekül ağırlıkları yağ asit kompozisyonlarına göre hesaplanmıștır.

Tablo 2. Biyodizel üretiminde kullanılan yağların yağ asidi kompozisyonları.

\begin{tabular}{|c|c|c|c|c|c|}
\hline \multirow[b]{3}{*}{ Yağ Asidi } & \multirow[b]{3}{*}{$\begin{array}{c}\text { Lipit } \\
\text { Sayısı }\end{array}$} & \multirow[b]{3}{*}{$\begin{array}{c}\text { Kimyasal } \\
\text { Formül }\end{array}$} & \multirow[b]{3}{*}{$\begin{array}{l}\text { Molekül } \\
\text { Ağırlığı }\end{array}$} & \multicolumn{2}{|c|}{ Yağ çeşidi } \\
\hline & & & & RAY & AAY \\
\hline & & & & \multicolumn{2}{|c|}{ Kütlesel (\%) } \\
\hline Mistirik & $\mathrm{C} 14: 0$ & $\mathrm{C}_{14} \mathrm{H}_{28} \mathrm{O}_{2}$ & 228.37 & 0.09 & 0.07 \\
\hline Palmitik & C16:0 & $\mathrm{C}_{16} \mathrm{H}_{32} \mathrm{O}_{2}$ & 256.42 & 5.33 & 6.29 \\
\hline Palmitoleik & C16:1 & $\mathrm{C}_{16} \mathrm{H}_{30} \mathrm{O}_{2}$ & 254.41 & 0.12 & 0.10 \\
\hline Heptadekanoik & $\mathrm{C} 17: 0$ & $\mathrm{C}_{17} \mathrm{H}_{34} \mathrm{O}_{2}$ & 270.45 & 0.14 & 0.03 \\
\hline Heptadesenoik & $\mathrm{C} 17: 1$ & $\mathrm{C}_{17} \mathrm{H}_{32} \mathrm{O}_{2}$ & 268.44 & 0.09 & - \\
\hline Stearik & C18:0 & $\mathrm{C}_{18} \mathrm{H}_{36} \mathrm{O}_{2}$ & 284.48 & 3.46 & 3.91 \\
\hline Oleik & $\mathrm{C} 18: 1$ & $\mathrm{C}_{18} \mathrm{H}_{34} \mathrm{O}_{2}$ & 282.46 & 37.13 & 28.58 \\
\hline Linoleik & $\mathrm{C} 18: 2$ & $\mathrm{C}_{18} \mathrm{H}_{32} \mathrm{O}_{2}$ & 280.45 & 52.01 & 57.04 \\
\hline Linolenik & $\mathrm{C} 18: 3$ & $\mathrm{C}_{18} \mathrm{H}_{30} \mathrm{O}_{2}$ & 278.43 & 0.43 & 0.05 \\
\hline Araşidik & $\mathrm{C} 20: 0$ & $\mathrm{C}_{20} \mathrm{H}_{40} \mathrm{O}_{2}$ & 312.53 & 0.17 & 0.27 \\
\hline Gadoleik & $\mathrm{C} 20: 1$ & $\mathrm{C}_{20} \mathrm{H}_{38} \mathrm{O}_{2}$ & 310.51 & - & 0.13 \\
\hline
\end{tabular}


Tablo 2. (Devam1).

\begin{tabular}{|c|c|c|c|c|c|}
\hline Behenik & $\mathrm{C} 22: 0$ & $\mathrm{C}_{22} \mathrm{H}_{44} \mathrm{O}_{2}$ & 340.58 & 0.66 & 0.71 \\
\hline Lignoserik & $\mathrm{C} 24: 0$ & $\mathrm{C}_{24} \mathrm{H}_{48} \mathrm{O}_{2}$ & 368.64 & 0.14 & 0.24 \\
\hline
\end{tabular}

Tablo 3. Deneylerde kullanılan yağların özellikleri.

\begin{tabular}{|c|c|c|c|}
\hline \multirow{2}{*}{ Özellik } & \multirow{2}{*}{ Birim } & \multicolumn{2}{|c|}{ Özellik değeri } \\
\cline { 3 - 4 } & & RAY & AAY \\
\hline Yoğunluk $\left(15^{\circ} \mathrm{C}\right)$ & $\mathrm{g} / \mathrm{cm}^{3}$ & 0.921 & 0.925 \\
\hline Viskozite $\left(40^{\circ} \mathrm{C}\right)$ & $\mathrm{mm}^{2} / \mathrm{s}$ & 32.57 & 36.47 \\
\hline Asit değeri & $\mathrm{mgKOH} / \mathrm{g}$ & 0.26 & 0.69 \\
\hline Alt 1sıl değer & $\mathrm{kJ} / \mathrm{kg}$ & 39482 & 39212 \\
\hline Su içeriği & $\mathrm{mg} / \mathrm{kg}$ & 264 & 356 \\
\hline Ortalama molekül ağırlığ & $\mathrm{g} / \mathrm{mol}$ & 879.59 & 879.14 \\
\hline
\end{tabular}

\subsection{2. Üretim yöntemi}

Asit değeri $(<1.0 \mathrm{mgKOH} / \mathrm{g})$ ve su içeriği $(<500 \mathrm{mg} / \mathrm{kg})$ uygun aralıklarda olan bitkisel kökenli yağlar (atık ya da kullanılmamış) için optimum transesterifikasyon parametreleri birçok çalışmada; 6:1 metanol:yağ oranı ve \%1 bazik katalizör olarak önerilmektedir [20-22]. Deneylerde kullanılan RAY ve AAY'nin asit değeri ve su içeriği sınır değerlerin altında olduğu için biyodizel üretimleri önerilen reaksiyon parametrelerinde ve metanolün kaynama noktasının biraz altındaki $60^{\circ} \mathrm{C}$ sicaklıkta gerçekleştirilmiştir. Tüm üretimlerde yağ miktarı $33 \mathrm{~kg}$ olarak alınmış, kimyasal malzemelerin miktarları yağ ağırlığına göre hesaplanmıştır. Biyodizel üretiminde öncelikle AAY filtre edilerek, içerisinde bulunan yabancı maddelerin uzaklaştırılması sağlanmıştır. RAY için filtre işlemi uygulanmamıştır. Metanol ve KOH'den meydana gelen metoksit karışımını oluşturmak için hesaplanan miktardaki $\mathrm{KOH}$, metanolün içine dökülmüş ve homojen bir metoksit karışımı elde etmek için karıştırma işlemi uygulanmıştır. Reaktör içine doldurulmuş olan yağ reaksiyon sicaklığının $\left(60^{\circ} \mathrm{C}\right)$ biraz üzerindeki bir sıcaklığa kadar ısıtılmış ve oda sıcaklığında hazırlanan metoksit karışımı, 1sıtılan yağ içine dökülmüştür. Daha sonra yağ ve metoksitten oluşan karışımın birbiri ile tamamen etkileşme girmesi ve mikrodalganın karışıma homojen şekilde etki etmesi için karıştırma işlemi başlatılmıştır. Karıştırma işlemiyle beraber reaksiyonun başladığı kabul edilmiştir. Üretilen biyodizelin reaksiyon zamanına bağlı olarak değișen ester içeriği ve üretim verimi değerlerinden transesterifikasyonun tamamlanma derecesini tespit etmek ve biyodizelin temel yakıt özellikleri olan yoğunluk ve kinematik viskozitesini ölçmek için mikrodalga destekli reaksiyonların 5., 10., 15., 20., 30., 45. ve 60. dakikalarında reaktörden $300 \mathrm{~g}$ ağırlığında numuneler alınmıştır. Konvansiyonel ısıtmanın kullanıldığı üretimde ise reaksiyonun daha yavaş ilerleyeceği beklenildiğinden reaksiyonun 15., 30., 45. ve 60. dakikalarında numuneler alınmıştır. Literatürdeki konvansiyonel üretimlerde optimum reaksiyon süresinin 60 dakika olmasından dolayı deneylerde reaksiyonu süresi 60 dakika (maks) ile sınırlandırılmıştır. Numuneler reaktörden alındıktan sonra soğuk su banyosunda soğutulmuş (reaksiyonun durması için) ardında da ayırma hunilerine transfer edilerek dinlendirme adımına geçilmiştir. Kısa bir dinlenme süresinin sonra biyodizel-gliserol faz ayrışması meydana gelmiş, daha yoğun olan gliserol ayırma hunisinin alt kısmına çökelmiştir. Dinlendirme sonunda çökelen gliserol fazı ortamdan uzaklaştırılarak ham biyodizel elde edilmiştir. 
Biyodizel numunelerinin dinlendirme işlemi ve oluşan fazlar Şekil 4'te gösterilmiştir. Ardından, ham biyodizelin safsızlıklarından (gliserol, tri-di-mono gliserit vb.) arındırılması için saflaştırma adımına geçilmiştir. Biyodizel ağırlığının üçte biri kadar $\mathrm{su}, 55^{\circ} \mathrm{C}$ sıcaklığa kadar isitılarak ham biyodizelin üzerine dökülmüş ve oluşan yeni karışım çalkanarak suyun safsızlıkları absorbe etmesi sağlanmıştır. Sonraki adımda suyun çökelmesi için yeniden dinlendirme işlemine geçilmiş, yoğunluk farkından dolayı dibe çöken su biyodizelden uzaklaştırılmıştır. Yıkama prosesi aynı işlem sırasıyla her numuneye 4 defa uygulanmıştır. Ham biyodizelin 1. ve 4. yıkama işlemleri Şekil 5'te gösterilmiştir. Şekilden de görüleceği üzere, ham biyodizel içerisinde yüksek miktarda bulunan safsızlıklar ilk yıkama sonunda oluşan atık su renginin beyaza yakın olmasına neden olmuştur. Son yıkama sonunda ise atık su içinde eser miktarda safsızlık olduğu için suyun rengi belirgin şekilde berraklaşmıştır. Saflaştırılan biyodizel, su ve metanol artıklarının buharlaştırılması için ETÜV fırınında $110^{\circ} \mathrm{C}$ 'de kurutulmuştur. Son adım olarak ise biyodizel filtrelenerek yakıt analizlerinin yapılması için stoklanmıştır.

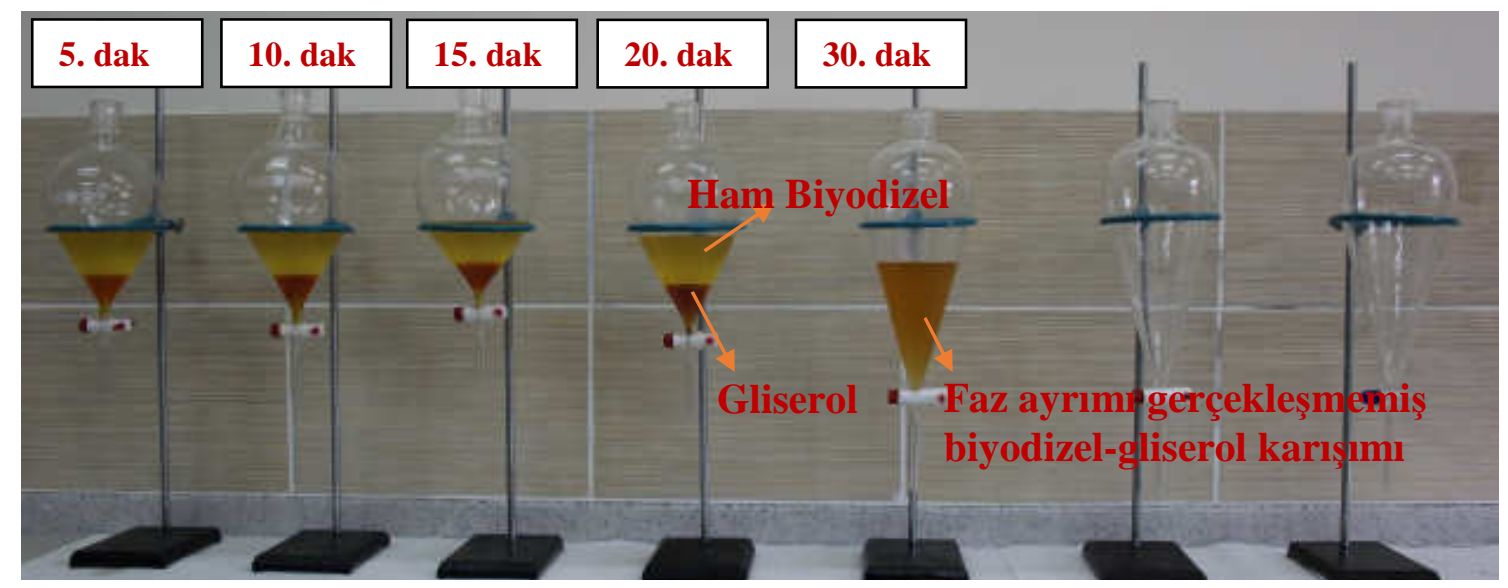

Şekil 4. Ham biyodizel-gliserol faz ayrımı.
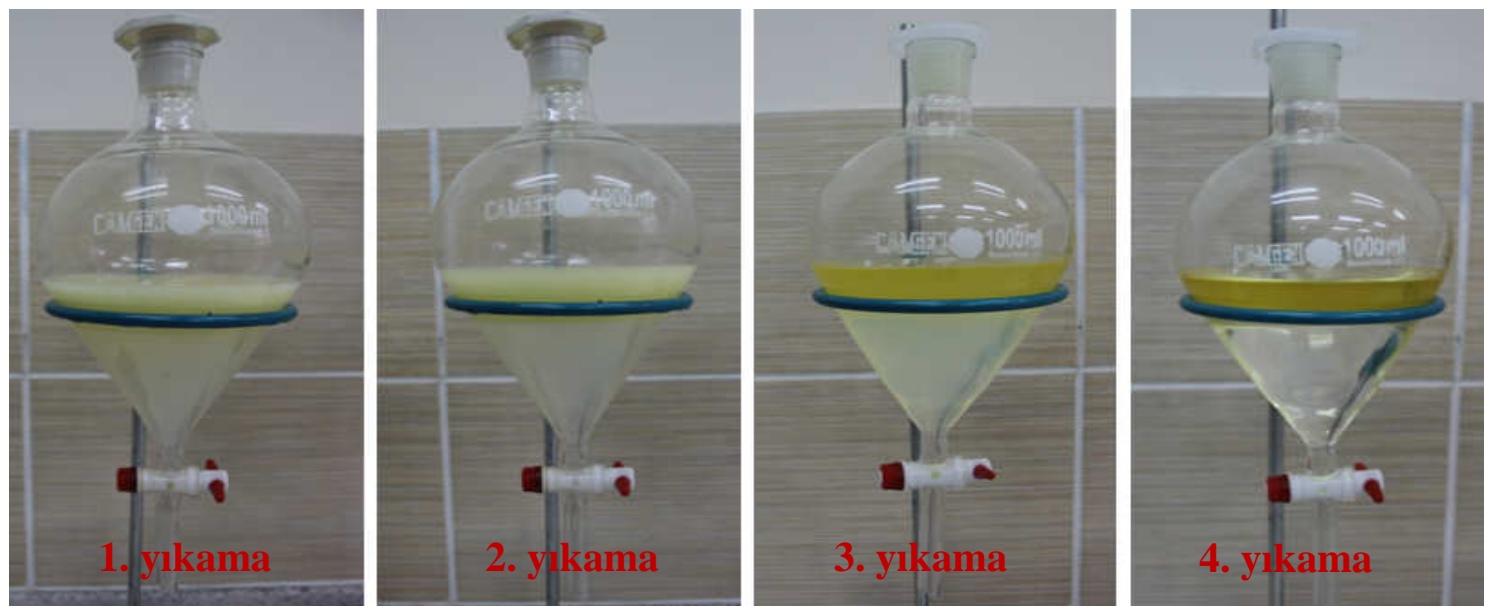

Şekil 5. Ham biyodizelin yıkanma aşamaları.

\subsubsection{Yă̆ ve biyodizel özelliklerinin belirlenmesi}

Deneylerde kullanılan yağların ve üretilen biyodizel numunelerinin yoğunlukları ISO 4787, kinematik viskoziteleri EN ISO 310, asit sayıs1 değerleri ise EN 14104 standartlarında belirtilen yöntemlerce Balıkesir Üniversitesi Makine Mühendisliği Bölümü Biyoyakıt Laboratuvarında ölçülmüştür. Biyodizel verimi, elde edilen biyodizel 
miktarının kullanılan yağ ağırlığına oranlanmasıyla $\left(\mathrm{m}_{\text {biyodizel }} / \mathrm{m}_{\text {yağ }}\right)$ hesaplanmıștır. RAY'in yağ asit kompozisyon içeriği üretici firmadan temin edilmiş, AAY'nin ise TUBİTAK MAM Gıda Enstitüsü laboratuvarlarında ölçülmüştür. Yağların ortalama molekül ağırlıkları yağ asit kompozisyonlarına göre hesaplanmıştır. Yağların su içeriği ve biyodizel numunelerinin metil ester içerikleri, hizmet alımı yoluyla TS EN ISO/IEC 17025:2012 standardına göre akredite olan Malatya Üniv. Akaryakıt ve Petrol Araştırma Laboratuvarlarında, EN 14214'te belirtilen ilgili test metoduna göre tespit edilmiştir.

\section{Sonuçlar ve değerlendirme}

\subsection{RAY'dan biyodizel üretimi}

Mikrodalga ve konvansiyonel yöntemler ile; 6:1 molar metanol:yağ, ağırlıkça \%1 KOH ve $60^{\circ} \mathrm{C}$ reaksiyon koşullarında gerçekleştirilen RAY'dan pilot ölçekte biyodizel üretimleri için transesterifikasyon süresine bağlı değișen biyodizel numunelerinin temel yakıt özellikleri Şekil 6, Şekil 7 ve Tablo 4'te gösterilmiştir.

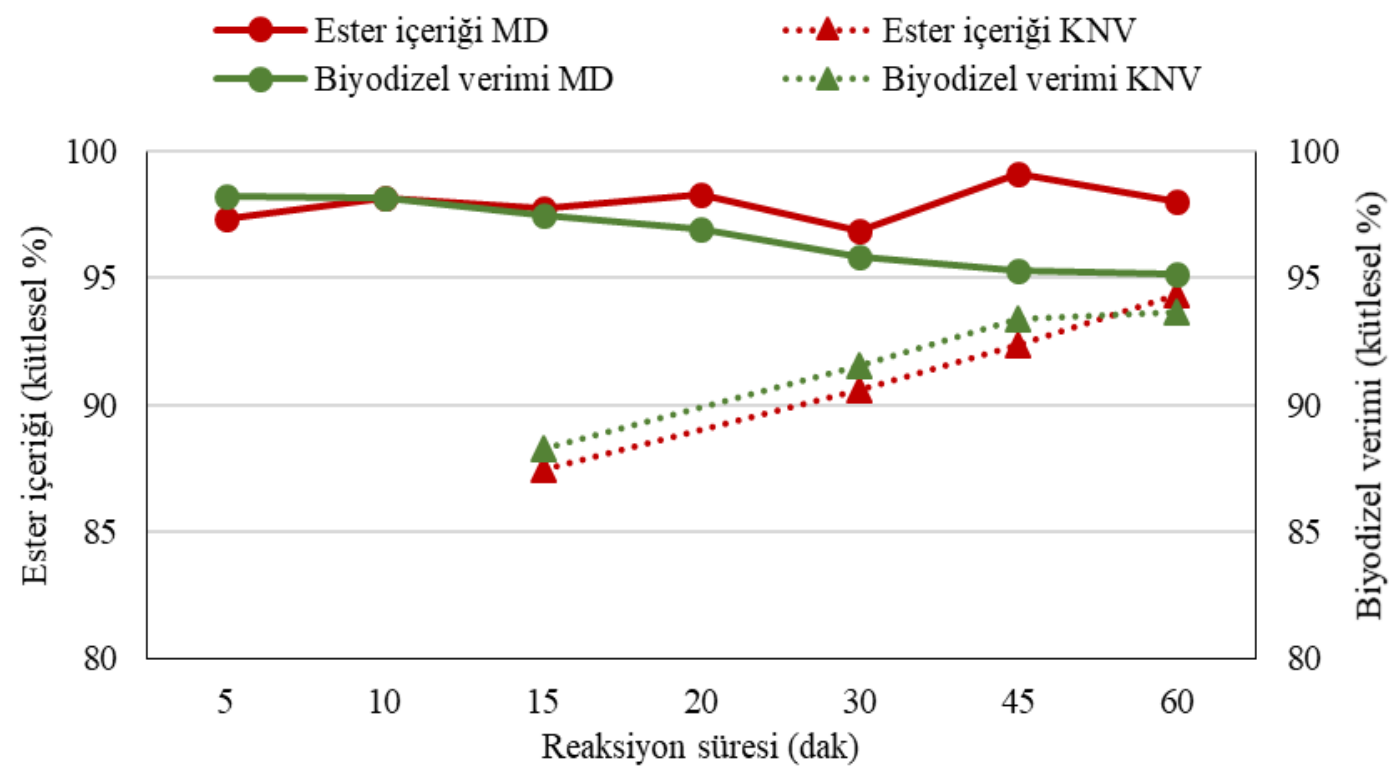

Şekil 6. Reaksiyon zamanına bağlı ester içeriği ve dönüşümm veriminin değişimi. 


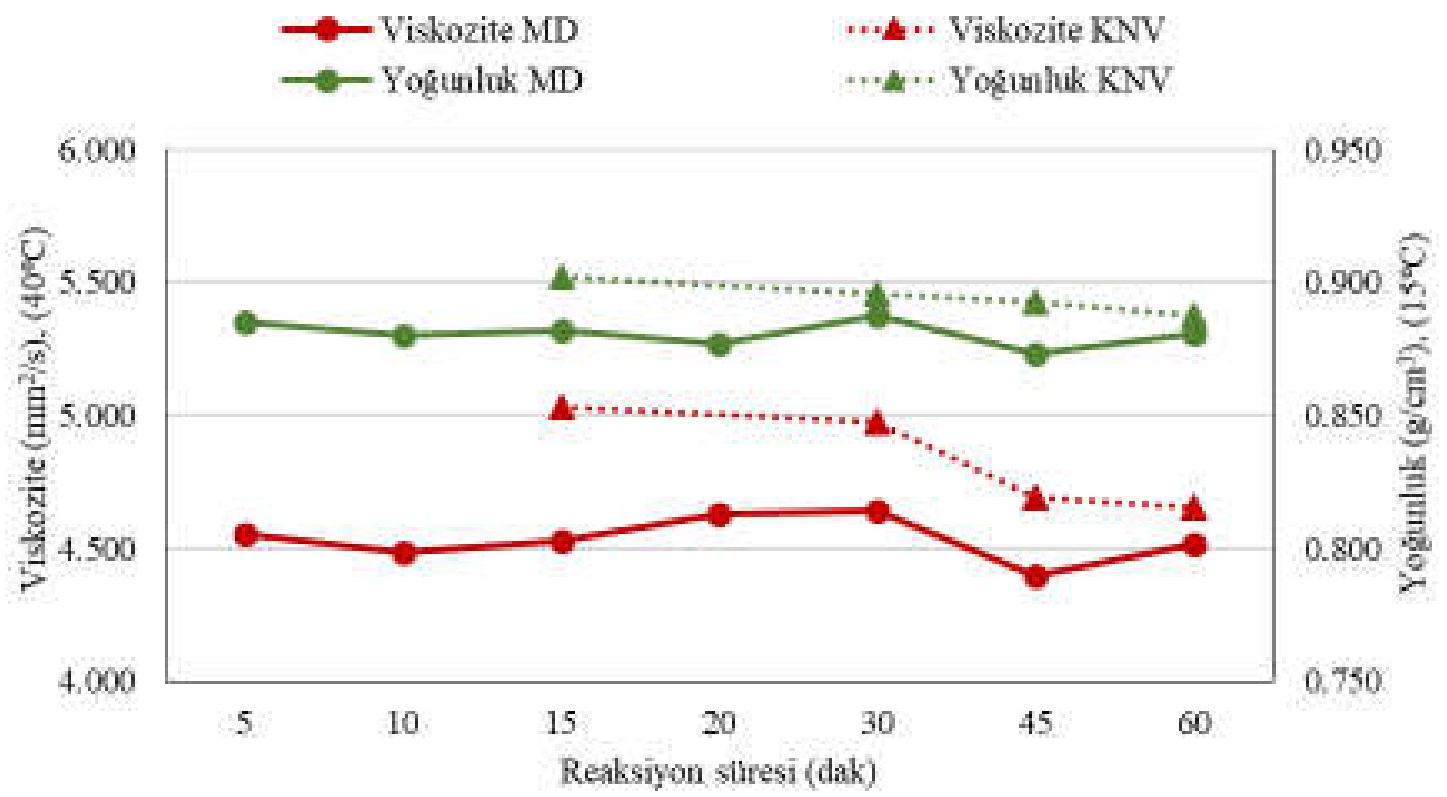

Şekil 7. Reaksiyon zamanına bağlı viskozite ve yoğunluğun değişimi.

Tablo 4. Reaksiyon zamanına bağlı RAY biyodizel yakıt özelliklerinin değişsimi.

\begin{tabular}{|c|c|c|c|c|c|c|c|c|}
\hline \multirow{4}{*}{$\begin{array}{l}\text { Reaksiyon } \\
\text { süresi }\end{array}$} & \multicolumn{2}{|c|}{\begin{tabular}{|c} 
Yoğunluk $\left(15^{\circ} \mathrm{C}\right)$ \\
$\left(\mathrm{gcm}^{-3}\right)$
\end{tabular}} & \multicolumn{2}{|c|}{$\begin{array}{c}\text { Viskozite }\left(40^{\circ} \mathrm{C}\right) \\
\left(\mathrm{mm}^{2} \mathrm{~s}^{-1}\right) \\
\end{array}$} & \multicolumn{2}{|c|}{$\begin{array}{l}\text { Ester içeriği } \\
\text { (küitlesel \%) }\end{array}$} & \multicolumn{2}{|c|}{$\begin{array}{c}\text { Biyodizel verimi } \\
(\text { kütlesel \%) }\end{array}$} \\
\hline & \multicolumn{8}{|c|}{ EN 14214 standardı limitleri } \\
\hline & \multicolumn{2}{|c|}{$0.860-0.90$} & \multicolumn{2}{|c|}{$3.5-5.0$} & \multicolumn{2}{|c|}{$\min .96 .5$} & \multicolumn{2}{|r|}{ - } \\
\hline & MD & KNV & MD & KNV & MD & KNV & MD & KNV \\
\hline 5 & 0.885 & - & 4.554 & - & 97.38 & - & 98.21 & - \\
\hline 10 & 0.880 & - & 4.483 & - & 98.14 & - & 98.18 & - \\
\hline 15 & 0.882 & 0.902 & 4.529 & 5.029 & 97.79 & 87.48 & 97.46 & 88.31 \\
\hline 20 & 0.877 & - & 4.628 & - & 98.30 & - & 96.92 & - \\
\hline 30 & 0.888 & 0.896 & 4.641 & 4.974 & 96.88 & 90.60 & 95.83 & 91.56 \\
\hline 45 & 0.873 & 0.893 & 4.395 & 4.695 & 99.13 & 92.40 & 95.31 & 93.42 \\
\hline 60 & 0.881 & 0.888 & 4.515 & 4.655 & 98.01 & 94.33 & 95.14 & 93.67 \\
\hline
\end{tabular}

Şekil 6'daki grafik ve Tablo 4'deki veriler incelendiğinde; mikrodalga 1şıma altında RAY'dan 5 dakikalık transesterifikasyon ile üretilen biyodizelin ester içeriği oranının, Avrupa Birliği Biyodizel Standartları EN 14214'te belirtilen asgari sınırın (\%96.5) üzerinde olduğu ve bu değerin reaksiyon süresi ile neredeyse hiç değişmediği görülmektedir. Reaksiyonun 5. dakikasında \%97.38 olan ester içeriği değeri, 30. dakikada \%96.88, en uzun reaksiyon süresi olan 60. dakikada ise \%98.01 olarak ölçülmüştür. Bu veriler, metil ester dönüşümünün 5. dakikada pik noktasına ulaştığını ve reaksiyonun büyük ölçüde tamamlandığını göstermektedir. Reaksiyon süresine bağlı ester içeriğindeki eser miktardaki değişimlerin, yapılan ölçüm hatalarından ve saflaştırma proseslerinde (ayırma hunilerinin çalkalanması) aynı hassasiyetin uygulanamamasından kaynaklandığı söylenebilir. Birçok çalışmada, konvansiyonel metotlar ile benzer reaksiyon parametrelerinde gerçekleştirilen ayçiçeği yağ transesterifikasyonlarının çok daha uzun sürelerde tamamlandığı rapor edilmiştir. 
Örneğin; Freedman ve ark. [3], 6:1 molar alkol ve bazik katalizör ( $\mathrm{KOH}$ veya $\mathrm{NaOH})$ kullanımında ayçiçek yağı ve diğer bitkisel yağların $60{ }^{\circ} \mathrm{C}$ ve üstü sıcaklıklarda 60 dakikada, $32{ }^{\circ} \mathrm{C}$ sicaklıkta ise 240 dakikada $\% 99$ oranında metil, etil ve bütil esterlerine dönüşebildiklerini belirtmişlerdir. Konvansiyonel metot ile üretimin gerçekleştirildiği bir başka çalışmada, 60 dakikalık bazik transesterifikasyon ile \%96.6 ester içeriğine sahip ayçiçek metil ester elde dilmiştir [23]. Bir diğer çalışmada ise Alptekin ve ark. [24], 6:1 molar metanol ve ağırlıkça \%1 KOH kullanarak ayçiçek yağından \%97.1 ester içeriğine sahip biyodizeli 240 dakikalık transesterifikasyon ile üretmişlerdir. Diğer taraftan mikrodalga altında üretilen numunelerin biyodizel verimleri incelendiğinde; bu değerin reaksiyonun ilk dakikalarında daha yüksek, ilerleyen reaksiyon zamanlarında ise kısmi bir düşüş eğiliminde olduğu görülmektedir. 5. (\%98.21) ve 60. dakika (\%95.14) arasında yaklaşık \%3'lük bir fark oluşmuştur. Benzer sonuçların elde edildiği çalışmalarda, bu durumun transesterifikasyon tamamlandıktan sonra devam ettirilen reaksiyonlarda meydana gelen hidroliz reaksiyonu ile esterlerin serbest yağ asitlerine (SYA) ve sabuna dönüşmesinden, ayrıca artan reaksiyon süresi ve sicaklığı ile gliserol çözünürlüğünün artmasından kaynaklandığı belirtilmektedir [25, 26]. 5. dakika sonunda hesaplanan verim değeri, benzer reaksiyon koşullarında konvansiyonel metotlar ile gerçekleştirilmiş çalışmalarda elde edilen verim değerinin birçoğundan daha yüksek bulunmuştur. Ayçiçek yağından bazik transesterifikasyon ile biyodizel üretimlerinde; Dias ve ark. [27] 60 dakikada yaklaşık \%97, Tomasevic ve Marinkovic [28] 30 dakikada > 90\%, Rashid ve ark. ise [29] 60 dakikada \%97.1'lik biyodizel verimi elde edebilmişlerdir. Şekil 7 ve Tablo 4'teki yoğunluk ve viskozite (kinematik) değerleri incelendiğinde, 5 dakikalık reaksiyon sonunda üretilen biyodizel numunesinin EN 14214 biyodizel standartlarına uyumlu yoğunluk ve kinematik viskozite değerlerine sahip olduğu görülmektedir. Reaksiyon 5 dakika sonunda tamamlandığı için daha sonra alınan numunelerin yoğunluk ve viskozite değerlerinde bir değişme yaşanmamıştır. Tüm bu verilere göre; mikrodalga 1şıma altında, 6:1 molar oranda metanol ve $\% 1 \mathrm{KOH}$ kullanımıyla gerçekleştirilen $60^{\circ} \mathrm{C}$ 'deki pilot ölçekli RAY transesterifikasyonunun 5 dakika sonunda tamamlandığı ve konvansiyonel metotlara göre çok hızlı sayılabilecek bu sürede içinde EN 14214 standartlarında biyodizel üretilebileceği görülmüştür.

Konvansiyonel metotlar ile aynı reaksiyon koşullarında gerçekleştirilen deney sonuçları incelendiğinde, ester içeriği ve biyodizel verim değerlerinin reaksiyon süre ile paralel olarak arttığ 1 anlaşılmaktadır. Reaksiyonun 15. dakikasında \%87.48 olan ester içeriği, 60. dakika sonunda \%94.33'e kadar artış göstermiş ancak bu değer EN 14214 standardı dışında kalmıştır. Kademeli olarak artan ester içeriğinin \%96.5 bandına ulaşması için reaksiyonun daha uzun sürdürülmesi gerektiği görülmüştür. Biyodizel verimi de ester içeriğine benzer olarak reaksiyon süresiyle artış eğilimi göstermiş; 15. dakikada \%88.31 olarak hesaplanan bu değer, 60. dakika sonunda \%93.67 olarak bulunmuştur. Yapılan ölçümlerde, biyodizel numunelerinin yoğunluk ve kinematik viskozite değerleri 15 dakikalık üretim için standart dişında bulunmuştur. 30 dakikada üretilen numunenin viskozite değeri $5 \mathrm{~mm}^{2} / \mathrm{s}$ 'lik standart değerinin hemen altında $4.974 \mathrm{~mm}^{2} / \mathrm{s}$ olarak, yoğunluk değeri ise $0.896 \mathrm{~g} / \mathrm{cm}^{3}$ olarak ölçülmüştür. Artan süre ile biyodizel numunelerindeki ester içeriği oranının dolayısıyla saflık derecelerinin artması yoğunluk ve özellikle viskozite değerlerinde iyileşmeye neden olmuştur. Reaksiyonun 60 . dakikası için bu değerler kinematik viskozite için $4.655 \mathrm{~mm}^{2} / \mathrm{s}$, yoğunluk için ise 0.888 $\mathrm{g} / \mathrm{cm}^{3}$ 'e kadar düşmüştür. 


\subsection{AAY'den biyodizel üretimi}

Mikrodalga ışıma altında; 6:1 molar metanol:yağ, ağırlıkça $\% 1 \mathrm{KOH}$ ve $60^{\circ} \mathrm{C}$ reaksiyon koşullarında gerçekleștirilen AAY'den pilot ölçekte biyodizel üretimi için transesterifikasyon süresine bağlı değișen biyodizel numunelerinin temel yakıt özellikleri Şekil 8, Şekil 9 ve Tablo 5'te gösterilmiştir.

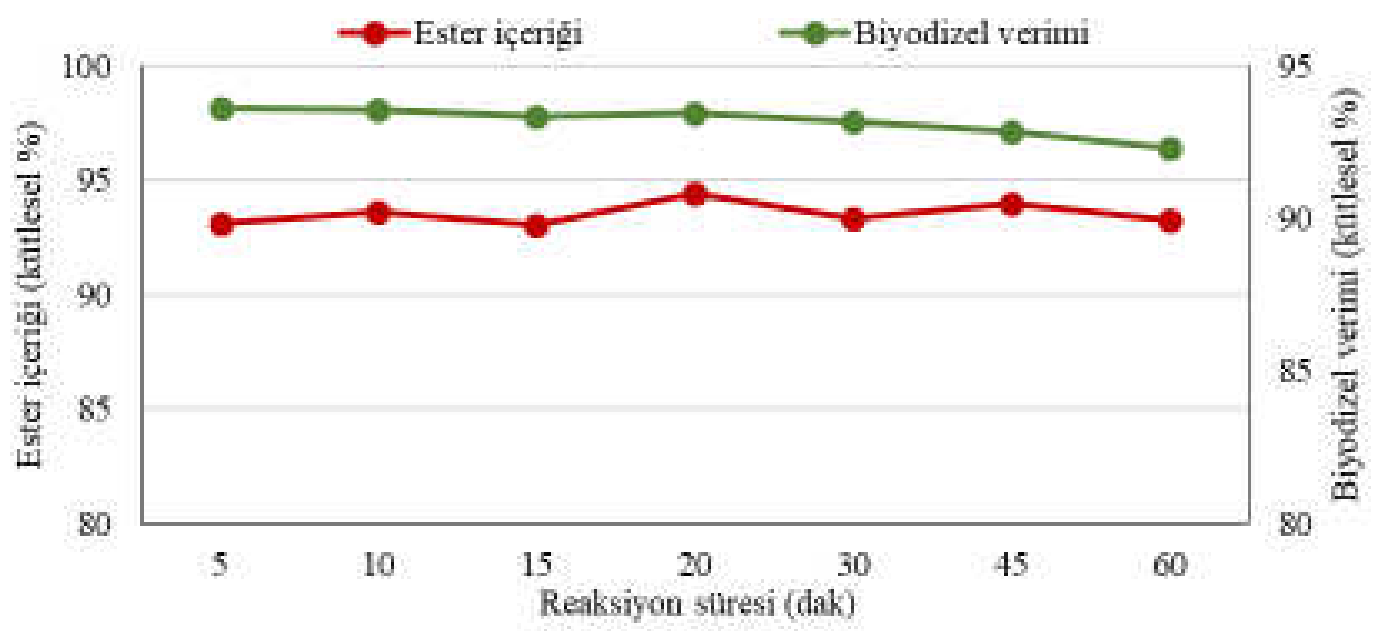

Şekil 8. Reaksiyon zamanına bağlı ester içeriği ve dönüşüm veriminin değişimi.

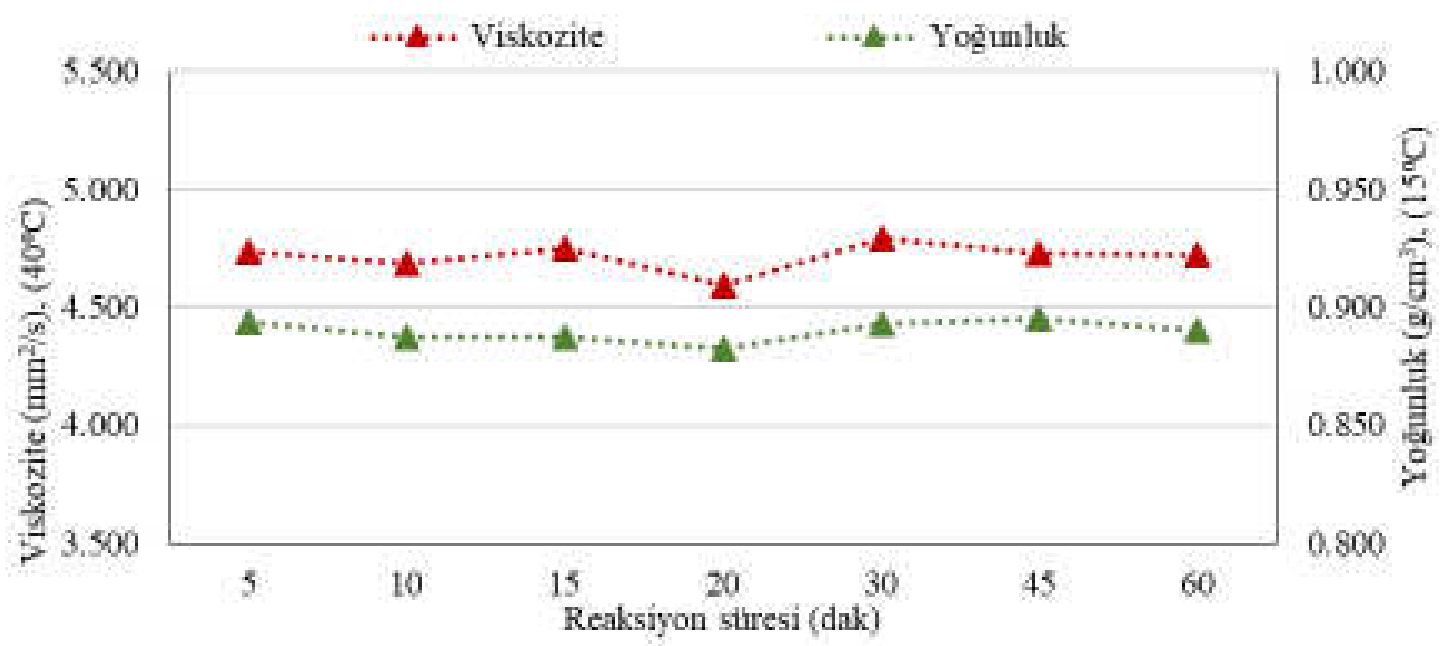

Şekil 9. Reaksiyon zamanına bağlı kinematik viskozite ve yoğunluğun değiş̧imi.

Tablo 5. Reaksiyon zamanına bağlı AAY biyodizel yakıt özelliklerinin değișimi.

\begin{tabular}{|c|c|c|c|c|}
\hline \multirow{2}{*}{$\begin{array}{c}\text { Reaksiyon } \\
\text { süresi }\end{array}$} & $\begin{array}{c}\text { Yoğunluk }\left(\mathbf{1 5}^{\circ} \mathbf{C}\right) \\
\left(\mathbf{g c m}^{-3}\right)\end{array}$ & $\begin{array}{c}\left.\text { Viskozite } \mathbf{( 4 0}^{\circ} \mathbf{C}\right) \\
\left(\mathbf{m m}^{\mathbf{2}} \mathbf{s}^{-1}\right)\end{array}$ & $\begin{array}{c}\text { Ester içeriği } \\
(\text { küitlesel \%) }\end{array}$ & $\begin{array}{c}\text { Biyodizel } \\
\text { verimi } \\
(\text { küitlesel \%) }\end{array}$ \\
\cline { 2 - 5 } & & \multicolumn{4}{|c|}{ EN 14214 standardı limitleri } \\
\cline { 2 - 5 } & $\mathbf{0 . 8 6 0 - 0 . 9 0}$ & $\mathbf{3 . 5 - 5 . 0}$ & min. 96.5 & - \\
\hline 5 & 0.894 & 4.732 & 93.11 & 93.61 \\
\hline 10 & 0.887 & 4.685 & 93.64 & 93.55 \\
\hline 15 & 0.887 & 4.746 & 93.02 & 93.34 \\
\hline 20 & 0.882 & 4.592 & 94.41 & 93.45 \\
\hline
\end{tabular}


Tablo 5. (Devami).

\begin{tabular}{|l|l|l|l|l|}
\hline 30 & 0.893 & 4.793 & 93.35 & 93.15 \\
\hline 45 & 0.895 & 4.731 & 93.98 & 92.87 \\
\hline 60 & 0.890 & 4.719 & 93.27 & 92.31 \\
\hline
\end{tabular}

Şekil 8 ve Tablo 5'teki verilere göre; tüm numune ester içeriklerinin \%93.02 ila \%94.41 aralığındaki sabit sayılabilecek değerlerde seyrettiği ve reaksiyon süresiyle bağlantılı bir değişimin meydana gelmediği görülmektedir. Biyodizel verim değerlerinin reaksiyon zamanına bağlı değişimi de ester içeriklerine çok benzer bir karakteristik göstermektedir. Yapılan hesaplamalarda en düşük biyodizel verimi \%92.31, en yüksek biyodizel verimi ise \%93.45 olarak bulunmuştur. Bu değerlerden reaksiyonun 5 dakikada denge konumuna geldiği ve ürün yönünde daha fazla ilerleyemediği anlaşılmaktadır. Transesterifikasyon reaksiyonlarında istenen dönüşüm (>\%95) ve EN 14214 standartlarında şart koşulan \%96.5 ester içerik değerlerine ulaşılamamasının nedeni, AAY'nin kullanılmamış yağlara göre yağ kalitesinin düşük olması olarak yorumlanabilir. Atık yağların kullanılmamış yağlara göre daha yüksek olan serbest yağ asidi (SYA) ve sabunlaşma değeri, reaksiyonda ester içeriği ve dönüşüm verimini azaltan faktörler olarak bilinmektedir. Atık yağ içindeki SYA reaksiyon karışımında bulunan baz katalizörü harcar ve sabun oluşumuna neden olur. Sabun oluşumuyla azalan katalizör miktarı reaksiyonun katalitik verimi düşürür [30]. Karışım içindeki sabun ise ester ürünlerini azalttır ayrıca esterin gliserolün ve suyun ayrıştırılmasını da zorlaştırır [31]. AAY metil esterlerinin yoğunluk ve kinematik viskoziteleri, RAY metil esterlerine göre daha büyük değerlerde ölçülse de, tüm numunelerin bu özelliklerinin EN 14214 standartlarında uygun olduğu tespit edilmiştir. Aynı reaksiyon koşullarında mikrodalga 1şıma altında üretilen AAY biyodizel numunelerinin ortalama yoğunluk ve kinematik viskozite değerleri sırasıyla $4.714 \mathrm{~mm}^{2} / \mathrm{s}$ ve $0.890 \mathrm{~g} / \mathrm{cm}^{3}$; RAY biyodizel numunelerininki ise $4.535 \mathrm{~mm}^{2} / \mathrm{s}$ ve $0.881 \mathrm{~g} / \mathrm{cm}^{3}$ 'tür. AAY'den üretilen biyodizelin yakıt özellikleri ve reaksiyon veriminin RAY gibi olmasa da bu değerlerin; literatürde bulunan, konvansiyonel metotlar ile küçük ölçekte atık yağlar ya da pilot ölçekte atık veya kullanılmamış yağlar kullanılarak gerçekleştirilen transesterifikasyonlardan elde edilen ester içeriği ve biyodizel verim değerlerine çok yakın veya daha yüksek olduğu görülmüştür. Örneğin, Atapour ve ark. [32] gerçekleştirdikleri biyodizel üretimlerinde, optimum bazik transesterifikasyon parametrelerinde atık kızartma yağından 45 dakika sonunda \%92.05 biyodizel verimi elde edebilmişlerdir. Sabudak ve ark [33], 50 L hacimli bir biyodizel reaktörü kullanarak, ön iyileştirme işlemi uyguladıkları atık kızartma yağından bazik transesterifikasyon ile 60 dakika sonunda sulu yıkama saflaştırma işlemi ile birlikte \%95.6 ester içeriğine sahip biyodizel üretmiştir. Yapılan bir başka pilot ölçekli (241 L reaktör hacmi) çalışmada ise kullanılmamış nötr pamuk yağından 120 dakikalık bazik transesterifikasyon ile ancak \%86.12 ester içeriğine sahip biyodizel üretilebilmiştir [34]. Sonuç olarak mikrodalga altında AAY transesterifikasyonunda konvansiyonel metotlara kıyasla çok daha kısa sürede benzer sonuçlar elde edilse de, EN 14214 standartlarına uygun biyodizel üretimi geçekleştirilememiştir. Bunun sağlanması için mevcut katalizör miktarının (\%1.0) artırılması, farklı katalizör çeşitlerinin kullanılması ya da yağa ön iyileştirme uygulanması gibi yöntemler denenmesi gerektiği düşünülmüştür. 


\section{Sonuçlar}

Mikrodalga 1sıtma sistemi pilot ölçekli bir biyodizel reaktörüne adapte edilmiştir. Tasarlanan reaktörde; mikrodalga ışıma altında, rafine ayçiçek yağından 5 dakikalık transesterifikasyon ile temel yakıt özellikleri EN 14214 standartlarına uygun biyodizel üretilmiştir. Aynı reaktörde, aynı reaksiyon koşulları kullanılarak gerçekleştirilen konvansiyonel üretimde ise 60 dakikalık reaksiyon sonunda dahi mikrodalga 1sıtma ile elde edilen 5 dakikalık üretim çıktılarına ulaşılamamıştır. Mikrodalga 1sıtma sistemi kullanılarak atık ayçiçek yağı ile gerçekleştirilen üretimlerde, konvansiyonel metotlara göre daha iyi sonuçlar alınsa da, EN 14214 standartlarına uygun metil esterlerin üretilebilmesi için reaksiyon parametrelerinin optimize edilmesi gerektiği görülmüştür. Sonuç olarak bu çalışma ile birçok laboratuvar ölçekli biyodizel üretim çalışması tarafından aktarılan mikrodalga kullanım avantajlarının, ticari olarak kullanılabilecek bir sistemde de elde edilebileceği gösterilmiştir.

\section{Kaynaklar}

[1] Karabaş, H., Ayçiçek yağı metil esterinin donma ve parlama noktaları üzerine etkili olan parametrelerin belirlenmesi, Toprak Su Dergisi, 2(1), (2013).

[2] Fernando, S., Hall, C.,Jha, S., $\mathrm{NO}_{\mathrm{x}}$ reduction from biodiesel fuels, Energy \& Fuels, 20(1), 376-382, (2006).

[3] Freedman, B., Pryde, E.,Mounts, T., Variables affecting the yields of fatty esters from transesterified vegetable oils, Journal of the American Oil Chemists' Society, 61(10), 1638-1643, (1984).

[4] Özsezen, A.N. ve Çanakçi, M., Biyodizel ve karışımlarının kullanıldığı bir dizel motorda performans ve emisyon analizi, Pamukkale Üniversitesi Mühendislik Bilimleri Dergisi, 15(2), 173-180, (2009).

[5] Knothe, G., Current perspectives on biodiesel, Palmas (Colombia), (2003).

[6] Şanlı, H. ve M. Çanakçı, Dizel motorlar için yükselen bir alternatif yakıt: biyodizel, http://www.emo.org.tr/ekler/48a38cd25abeab0_ek.pdf, (14.01.2018).

[7] Meher, L., Sagar, D.V.,Naik, S., Technical aspects of biodiesel production by transesterification-a review, Renewable and Sustainable Energy Reviews, 10(3), 248-268, (2006).

[8] Kanitkar, A., Balasubramanian, S., Lima, M.,Boldor, D., A critical comparison of methyl and ethyl esters production from soybean and rice bran oil in the presence of microwaves, Bioresource technology, 102(17), 7896-7902, (2011).

[9] Nomanbhay, S. ve Ong, M.Y., A review of microwave-assisted reactions for biodiesel production, Bioengineering, 4(2), 57, (2017).

[10] Motasemi, F. ve Ani, F.N., A review on microwave-assisted production of biodiesel, Renewable and Sustainable Energy Reviews, 16(7), 4719-4733, (2012).

[11] Kuşlu, S. ve Bayramoğlu, M., Mikrodalgalar ile materyaller arasındakitermal olan ve olmayan etkileşimlerin incelenmesi ve mikrodalga kimyası, Pamukkale Üniversitesi Mühendislik Bilimleri Dergisi, 8(3), 395-405, (2002).

[12] Jermolovicius, L.A., et al., Microwave fast-tracking biodiesel production, Chemical Engineering and Processing: Process Intensification, 122, 380388, (2017). 
[13] Hernando, J., Leton, P., Matia, M.P., Novella, J.,Alvarez-Builla, J., Biodiesel and FAME synthesis assisted by microwaves: homogeneous batch and flow processes, Fuel, 86(10), 1641-1644, (2007).

[14] Azcan, N. ve Danisman, A., Alkali catalyzed transesterification of cottonseed oil by microwave irradiation, Fuel, 86(17), 2639-2644, (2007).

[15] Encinar, J., Gonzalez, J., Martínez, G., Sánchez, N.,Pardal, A., Soybean oil transesterification by the use of a microwave flow system, Fuel, 95, 386-393, (2012).

[16] Suryanto, A., Suprapto, S.,Mahfud, M., The production of biofuels from coconut oil using microwave, Modern Applied Science, 9(7), 93, (2015).

[17] Dubé, M., Tremblay, A.,Liu, J., Biodiesel production using a membrane reactor, Bioresource technology, 98(3), 639-647, (2007).

[18] Robinson, R.K., Encyclopedia of Food Microbiology. Academic press. (2014).

[19] Bitkisel Üretim İstatistikleri, (2017). https://biruni.tuik.gov.tr/bitkiselapp/bitkisel.zul, (26 Nisan 2017),

[20] Shahbazi, M.R., Khoshandam, B., Nasiri, M.,Ghazvini, M., Biodiesel production via alkali-catalyzed transesterification of Malaysian RBD palm oilcharacterization, kinetics model, Journal of the Taiwan Institute of Chemical Engineers, 43(4), 504-510, (2012).

[21] Pullen, J. ve Saeed, K., Investigation of the factors affecting the progress of base-catalyzed transesterification of rapeseed oil to biodiesel FAME, Fuel Processing Technology, 130, 127-135, (2015).

[22] Wang, Y., Ou, S., Liu, P., Xue, F.,Tang, S., Comparison of two different processes to synthesize biodiesel by waste cooking oil, Journal of Molecular Catalysis A: Chemical, 252(1), 107-112, (2006).

[23] Karabaş, H., Ayçiçek yağı biyodizelinin ester dönüşüm oranı üzerine etkili olan parametrelerin optimizasyonu, Adnan Menderes Üniv. Ziraat Fakültesi Dergisi, 10(1), 1-5, (2013).

[24] Alptekin, E. ve Canakci, M., Characterization of the key fuel properties of methyl ester-diesel fuel blends, Fuel, 88(1), 75-80, (2009).

[25] Chen, K.-S., Lin, Y.-C., Hsu, K.-H.,Wang, H.-K., Improving biodiesel yields from waste cooking oil by using sodium methoxide and a microwave heating system, Energy, 38(1), 151-156, (2012).

[26] Leung, D. ve Guo, Y., Transesterification of neat and used frying oil: optimization for biodiesel production, Fuel Processing Technology, 87(10), 883-890, (2006).

[27] Dias, J.M., Alvim-Ferraz, M.C.,Almeida, M.F., Comparison of the performance of different homogeneous alkali catalysts during transesterification of waste and virgin oils and evaluation of biodiesel quality, Fuel, 87(17), 3572-3578, (2008).

[28] Tomasevic, A. ve Siler-Marinkovic, S., Methanolysis of used frying oil, Fuel Processing Technology, 81(1), 1-6, (2003).

[29] Rashid, U., Anwar, F., Moser, B.R.,Ashraf, S., Production of sunflower oil methyl esters by optimized alkali-catalyzed methanolysis, Biomass and bioenergy, 32(12), 1202-1205, (2008).

[30] Özsezen, A., Atık palmiye yağından üretilen biyodizelin motor performans ve emisyon karakterleri üzerine etkisinin incelenmesi. Doktora Tezi, Kocaeli Üniversitesi Fen Bilimleri Enstitüsü, (2007).

[31] Canakci, M. ve Özsezen, A.N., Evaluating waste cooking oils as alternative diesel fuel, Gazi University Journal of Science, 18(1), 81-91, (2005). 
[32] Atapour, M., Kariminia, H.-R.,Moslehabadi, P.M., Optimization of biodiesel production by alkali-catalyzed transesterification of used frying oil, Process Safety and Environmental Protection, 92(2), 179-185, (2014).

[33] Sabudak, T. ve Yildiz, M., Biodiesel production from waste frying oils and its quality control, Waste Management, 30(5), 799-803, (2010).

[34] Demir, B., Küçük ölçekli bir biyodizel sisteminin oluşturulması, elde edilen pamuk yağı metil esterin motor performans testleri, enerjetik ve ekserjetik değerlendirilmesi, Doktora Tezi, Ege Üniversitesi Fen Bilimleri Enstitüsü Güneş Enerjisi Anabilim Dal, (2009). 